\title{
Pericardial necrosis - a rare clinical condition case report
}

\author{
Iveta Tashevaa, Ivo Petrova, Zoran Stankova, Jivka Stoykova ${ }^{a}$, lana Simova ${ }^{b}$, \\ Maria Dotseva $^{b}$, Galina Georgievac, Silvia Pavlova ${ }^{d}$
}

\author{
a Invasive Cardiology Department, Acibadem City Clinic University Hospital, Bulgaria \\ ${ }^{b}$ Cardiology Department, Acibadem City Clinic University Hospital, Bulgaria \\ 'Imaging Department, Acibadem City Clinic University Hospital, Bulgaria \\ ${ }^{d}$ Cardiology Department, Sofiamed University Hospital, Bulgaria
}

\section{ARTICLE INFO}

Article history:

Submitted: 17. 4. 2020

Revised: 26. 5. 2020

Accepted: 4. 6. 2020

Available online: 21. 10. 2020

\section{Klíčová slova:}

Bolest na hrudi

Nekróza perikardu

Neprítomnost ischemické choroby

srdeční

Keywords:

Absence of coronary artery disease

Chest pain

Pericardial necrosis

\section{SOUHRN}

Bolest na hrudi ve všech podobách je závažným dưvodem pro vyhledání lékařské péče. Třiapadesátiletá žena byla prijiata do nemocnice $s$ atypickou anginou pectoris a dušností. Po řadě vyšetření jak zobrazovacími metodami, tak invazivních i neinvazivních byla stanovena správná diagnóza, nekróza perikardu.

(c) 2020, ČKS

\section{ABSTRACT}

Chest pain in its varieties is a major reason for searching medical help. A 53-year-old woman was admitted to the hospital with complaints of atypical angina and shortness of breath. A series of imaging, invasive and non-invasive investigations were done to reach the right diagnosis - pericardial necrosis.

\section{Introduction}

The pericardial fat necrosis (PFN) is a rare benign condition which was first described in $1957 .{ }^{1}$ In a recent study its frequency was found to be about $2.15 \%$ among patients who underwent chest computed tomography (CT) for chest pain. ${ }^{2}$ It presents itself with prolonged chest pain usually at rest which usually worsens during inspiration. The pain may mimic pulmonary embolism and acute coronary syndrome, due to the typical location and irradiation, which makes the diagnosis difficult without laboratory, imaging and instrumental investigations. We present a case report of a woman with acute chest pain, admitted to the hospital for diagnosis and treatment.

\section{Case description}

Recently a 53-year-old woman was admitted to our hospital. She complained of retrosternal chest pain with irra- diation to the back, accompanied by shortness of breath. The pain had started less than 6 hours prior to hospitalization and was not provoked by physical exertion. She was hemodynamically stable with heart rate of 71 beats per minute and blood pressure of $95 / 70 \mathrm{mmHg}$ (measured on both arms). She was not febrile with normal oxygen saturation. Low extremities were with preserved peripheral pulsations. Her past medical history consisted of known enlargement of the ascending aorta, arterial hypertension with optimal medical treatment and Hashimoto disease with normal levels of thyroid hormones.

Differential diagnosis included coronary disease with the clinic of unstable angina, acute aortic syndrome and pulmonary embolism.

To start with the electrocardiography (ECG), which showed negative $T$ waves in inferior and precordial leads and did not exclude one or another differential diagnosis, except myocardial infarction with ST elevation. Echocardiography demonstrated preserved left ventricular ejection fraction with no segmental kinetic abnormalities. There

Address: Iveta Tasheva, MD, Invasive Cardiology Department, Acibadem City Clinic, Cardiovascular Center, Okolovrasten Pat Str. 1407 City, Bulgaria, e-mail: iveta_t@yahoo.com 


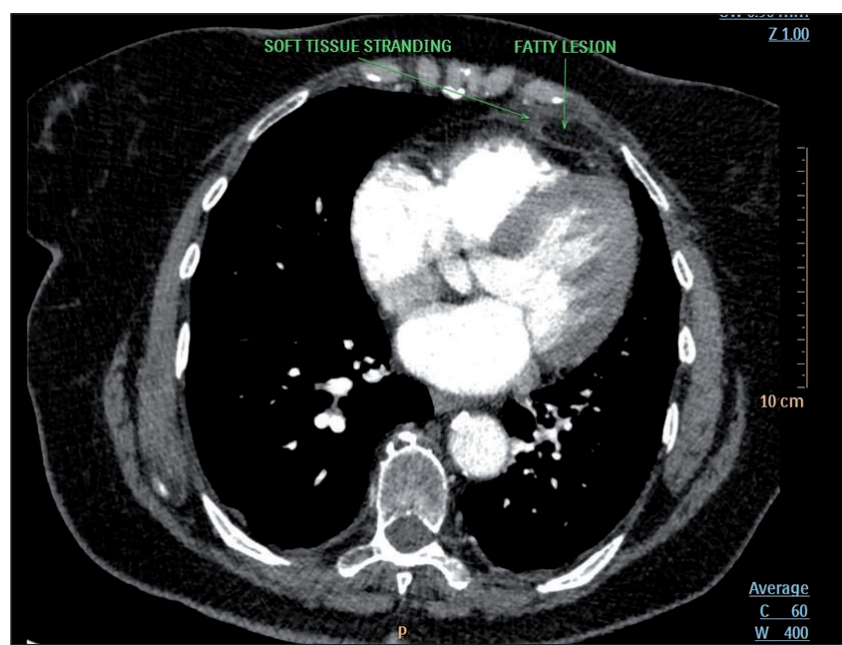

Fig. 1 - CT angiography showing fatty lesion - pericardial fat necrosis (see arrows) - fat-equivalent finding located in the inferior mediastinum to the left, pericardium and behind the chest wall at the level above the 5th rib.

was enlargement of the ascending aorta up to $44 \mathrm{~mm}$, all valves were with normal function. Laboratory tests were normal (including D-dimer), except for elevated high sensitive cardiac troponin T (hs-cTnT) $48 \mathrm{ng} / \mathrm{l}$ (reference limits 3-14 ng/l) and C-reactive protein (CRP) - $30 \mathrm{mg} / \mathrm{l}(0-5 \mathrm{mg} / \mathrm{l})$. Control markers for myocardial necrosis 3 hours later showed elevating troponin levels of $75 \mathrm{ng} / \mathrm{l}$. After calculation of Global Registry of Acute Coronary Events (GRACE) score - 151 points, corresponding to high mortality and morbidity risk, a decision for coronary angiography was undertaken, showing no coronary artery disease.

Acute aortic syndrome also came into consideration due to the past history of dilated ascending aorta, although there was no severe progression of the disease on echocardiography, as well as no present typical signs of acute aortic dissection. Based on ESC guidelines 2014 for diagnosis and treatment of aortic diseases we considered our patient to be high risk for acute aortic disease, so we performed CT aortography. On CT our radiologist did not find any evidence of acute aortic disease but after careful evaluation of the images, a fatty lesion in the left mediastinal space in the epicardium was found, corresponding to PFN (Fig. 1).

When closely evaluated the clinical symptoms, laboratory investigations and the typical finding on the $\mathrm{CT}$, they appeared to closely correlate with acute pericarditis with PFN.

Until the diagnosis was found the patient was admitted to hospital for close surveillance and monitoring. The usual cardiac therapy was not discontinued, including perindopril/amlodipine $-5 / 5 \mathrm{mg}$, bisoprolol $5+2,5 \mathrm{mg}$, rosuvastatin $10 \mathrm{mg}$. When the results of CT showed the diagnosis of pericardial fat necrosis, administration of ibuprofen was initiated - $600 \mathrm{mg}$ three times daily for 14 days with gradually lowering doses afterwards.

One month later the patient had no symptoms, as well as normal laboratory investigations. A follow-up CT scan at 1 month (Fig. 2) post-treatment showed significantly smaller lesion with thickening of the corresponding pericardium. ECG had positive dynamic with no ST-T changes.

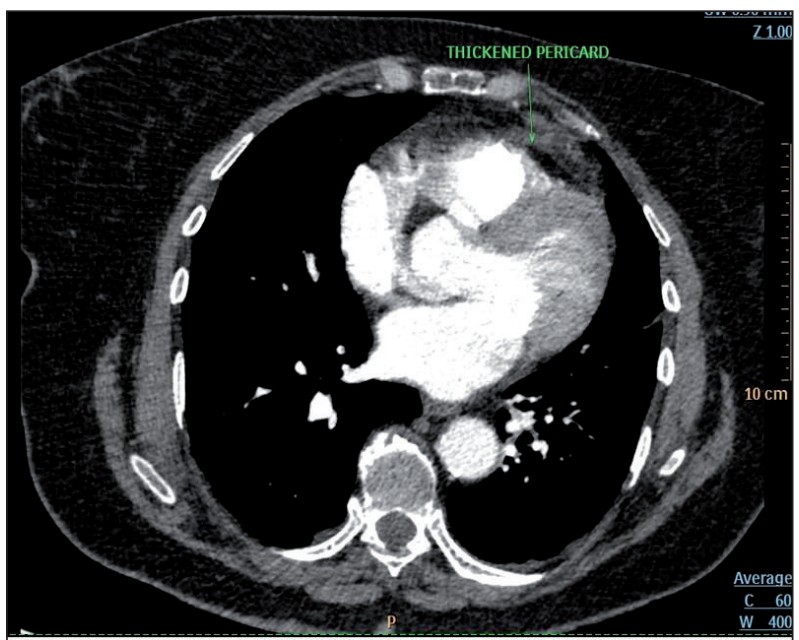

Fig. 2 - Control CT angiography after treatment showing reduced lesion and thickened pericard.

\section{Discussion}

Fat necrosis can occur in various sites in an organism. It is common in the breast and has also been described in peripancreatic fat in cases of pancreatitis, in epiploic appendagitis, in the subcutaneous fat, and, less frequently, in the epipericardial fat.

All patients presented with pleuritic chest pain on the same side as the lesion, in a study investigating a clinical series of such patients, founding also that, PFN is a more prevalent condition in the emergency department than previously thought. ${ }^{3}$ It is more commonly described on the left side and is self-limiting usually lasting a few days, however, there are case reports with lasting symptoms up to one year. Other associated symptoms include dyspnea, syncope, dizziness, tachycardia, and diaphoresis. Physical examination usually is unremarkable, because most of the suffering patients are young with no concomitant diseases.

The pathogenesis is unknown, but it has been postulated that vascular pedicle torsion is a possible cause. ${ }^{4}$ Other potential causes include the Valsalva maneuver or preexisting structural abnormalities of adipose tissue, such as lipoma, hamartoma, or lipomatosis. ${ }^{4}$

Chest radiographs are often normal during the first few days but usually will progress revealing round mass overlying the ipsilateral cardiophrenic angle, sometimes a pleural effusion, on the same side of the chest pain. CT can further provide characterization of the nonspecific paracardiac mass such as exact location. PFN can be diagnosed by identifying an ovoid lesion with fat attenuation with intrinsic and extrinsic soft-tissue stranding on chest $\mathrm{CT}^{5}$ Until the early 2000s, surgical removal of these lesions was deemed the treatment of choice, to exclude a neoplasm. Nowadays treatment is conservative (involving the use of anti-inflammatory agents), and symptoms resolve 3-4 days after treatment initiation. A follow-up CT examination is usually recommended to confirm resolution of the findings. ${ }^{6}$

PFN may be clinically mistaken for other severe causes of chest pain and dyspnea, most notably acute myocardial 
infarction, pulmonary thromboembolism or acute aortic dissection. However, laboratory tests and electrocardiogram in PFN are usually normal, unfortunately not in our clinical case, which made the diagnosis difficult to reach. Most of the cases published till now, present otherwise healthy young patients, with no laboratory changes, which can help guide clinicians to the correct diagnosis and avoid invasive tests. It is important for clinicians to be familiar of this disease process in order to manage it properly in the acute clinical setting. The difficulties in reaching the diagnosis is in the nonspecific presenting symptoms as well as unremarkable laboratory values and normal ECG, which however make the differentiation from other causes of chest pain.

\section{Conclusion}

Pericardial fat necrosis is a rare condition which may mimic a variety of severe acute diseases. Good knowledge of the disease and team work with radiologists may prevent confusion, misdiagnosis and unnecessary invasive investigations or surgical treatment. As far as proper diagnosis is made, the disease has benign and self-limiting nature.

\section{References}

1. Jackson RC, Clagett OT, McDonald JR. Pericardial fat necrosis: report of three cases. J Thorac Surg 1957;33:723-729.

2. Giassi KS, Costa AN, Bachion GH, et al. Epipericardial Fat Necrosis: Who Should Be a Candidate? AJR Am J Roentgenol 2016;207:773-777.

3. Giassi Kde S, Costa AN, Bachion GH, et al. Epipericardial fat necrosis: an underdiagnosed condition. Br J Radiol 2014;87(1038):20140118.

4. Lee BY, Song KS. Calcified chronic pericardial fat necrosis in localized lipomatosis of pericardium. AJR Am J Roentgenol 2007;188:W21-W24.

5. Bhatt MY, Martinez-Jiménez S, Rosado-de-Christenson ML, et al. Imaging manifestations of mediastinal fat necrosis. Case Rep Radiol 2013; 2013:323579.

6. Pineda V, Andreu J, Cáceres J, et al. Lesions of the cardiophrenic space: findings at cross-sectional imaging. RadioGraphics 2007;27:19-32. 